DOI: https://doi.org/10.24127/ajpm.v10i1.3122

\title{
KEMAMPUAN PEMECAHAN MASALAH SISWA DALAM MENYELESAIKAN SOAL OPEN ENDED BERBASIS BUDAYA JAMBI PADA MATERI PECAHAN
}

\author{
Muslimahayati $^{*}$, Syutaridho², Michrun Nisa Ramli ${ }^{3}$, Rahmat Nursalim $^{4}$ \\ $1^{*}, 2$ Pendidikan Matematika, Universitas Islam Negeri Raden Fatah, Palembang, Indonesia \\ ${ }^{3}$ Tadris Matematika, Universitas Islam Negeri Sulthan Thaha Saifuddin, Jambi, Indonesia \\ ${ }^{4}$ Matematika, Universitas Bengkulu, Bengkulu, Indonesia \\ ${ }^{*}$ Corresponding author.Jl. Prof Zainal Abidin Fikri, Palembang, Indonesia \\ E-mail: $\quad$ muslimahayati_uin@radenfatah.ac.id ${ }^{\left.1^{*}\right)}$ \\ syutaridho_uin@radenfatah.ac.id $^{2)}$ \\ micrunnisa@uinjambi.ac.id ${ }^{3}$ ) \\ rahmatnursalim@gmail.com $^{4}$
}

Received 30 September 2020; Received in revised form 01 March 2021; Accepted 30 March 2021

\begin{abstract}
Abstrak
Penelitian ini bertujuan untuk mendeskripsikan kemampuan pemecahan masalah siswa kelas VII MTs Negeri 3 Kota Jambi dalam menyelesaikan soal terbuka (open ended problem) berbasis budaya Jambi pada materi pecahan. Penelitian ini adalah penelitian deskriptif kualitatif. Penelitian dilaksanakan di MTs Negeri 3 Kota Jambi. Subjek penelitian adalah 6 siswa kelas VII MTs Negeri 3 Kota Jambi. Subjek penelitian terdiri dari 2 siswa dengan kemampuan tinggi, 2 siswa dengan kemampuan sedang dan 2 siswa dengan kemampuan rendah. Instrumen yang digunakan adalah tes dan wawancara. Analisis data dilakukan dengan reduksi data, penyajian data dan verifikasi atau kesimpulan. Teknik keabsahan data dilakukan dengan triangulasi sumber data. Hasil penelitian menunjukkan bahwa kemampuan pemecahan masalah (KPM) matematis siswa dalam menyelesaikan soal open ended berbasis budaya Jambi pada siswa kemampuan sedang dan tinggi tergolong pada kategori baik. Sedangkan untuk siswa kemampuan rendah berada pada kategori kurang sehingga siswa pada kemampuan rendah masih perlu bimbingan. Temuan penelitian menunjukkan bahwa penelitan berbasis budaya dalam penelitian ini menjadi sebuah metode baru yang mendekatkan siswa kepada pengetahuan serta menjadikan mereka mampu mentransformasikan hasil jawaban ke dalam bentuk dan prinsip yang kreatif tentang bidang ilmu.
\end{abstract}

Kata kunci : Budaya Jambi; kemampuan pemecahan masalah; pecahan; soal open ended.

\begin{abstract}
This study aims to describe problem solving ability seventh grade students of MTs Negeri 3 Jambi City in solving open ended problems based on Jambi culture on fractions. This research is a qualitative descriptive study. The research was conducted at MTs Negeri 3 Jambi City. The research subjects were 6 students of class VII MTs Negeri 3 Kota Jambi. The research subjects consisted of 2 students in the high category, 2 students in the medium category ang 2 students in the low category. The instruments used were tests, and interviews. Data analysis was carried out by data reduction, data presentation and verification or conclusion. The data validity technique was done by triangulating data sources. The results showed that the students' mathematical problem-solving abilities (KPM) in solving open-ended questions based on Jambi culture in students with moderate and high abilities were in the good category. Meanwhile, students with low ability are in the poor category, so students with low abilities still need guidance. This study found and show that the research based on culture in this study becomes a new method that brings students closer to knowledge and makes them able to transform the results of answers into creative forms and principles about the field of science.
\end{abstract}

Keywords: Fractions; Jambi culture; open ended problem; problem solving ability.

This is an open access article under the Creative Commons Attribution 4.0 International License 
DOI: https://doi.org/10.24127/ajpm.v10i1.3122

\section{PENDAHULUAN}

Pada dasarnya, masalah adalah situasi yang dihadapi seseorang, yang membutuhkan resolusi, dan jalan untuk mencapai solusi ini tidak segera diketahui (National Council of Teachers of Mathematics, 2000; Polya, 2014). Aziza (Aziza, 2019) menyatakan bahwa kemampuan pemecahan masalah pada dasarnya melibatkan proses belajar untuk menggunakan metode-metode ilmiah atau berpikir secara sistematis, logis, teratur, dan teliti.

Kemampuan pemecahan masalah biasanya diterapkan pada pemecahan masalah (soal) yang bersifat tidak rutin. Salah satu bentuk soal non rutin tersebut adalah soal open ended. Kriteria soal non rutin yaitu mampu mengeluarkan banyak ide, mampu menggunakan strategi penyelesaian tunggal (tertutup) dan tidak tunggal (terbuka), mampu menggunakan gabungan beberapa cara penyelesaian, mampu menguraikan secara terperinci, dan mencetuskan gagasan unik pada saat penyelesaian soal (Suandito, Darmawijoyo, \& Purwoko, 2013).

Beberapa penelitian yang berkaitan dengan kemampuan pemecahan masalah dan soal open ended telah banyak dilakukan dan menghasilkan kesimpulan penelitian. Pada penelitian Fitriyana dan Purwasi (Fitriana \& Purwasih, 2018) menggunakan pengembangan LKS berbasis pendekatan open ended terhadap kemampuan pemecahan masalah. Penelitian Yanti, Widada dan Zamzaili (Yanti, Widada, \& Zamzaili, 2018) melihat kemampuan pemecahan masalah open ended peserta didik sekolah negeri dan swasta dalam pembelajaran matematika realistic berorientasi etnomatematika bengkulu.

Selanjutnya, penelitian Thursina dan Sutriyono (Thursina \& Sutriyono, 2018) melihat profil kemampuan pemecahan masalah open ended pada materi bangun datar segiempat bagi siswa SMP. Penelitian Yesi, Citra dan Mariyam (Sapitri, Utami, \& Mariyam, 2019) menganalisis kemampuan pemecahan masalah matematis siswa dengan menggunakan soal open ended pada materi lingkaran ditinjau dari minat belajar siswa.

Kondisi di lokasi penelitian ternyata berbeda. Berdasarkan hasil observasi dan wawancara kepada guru mata pelajaran matematika ditemukan bahwa siswa jarang dilatih dengan soalsoal yang bersifat non rutin. Padahal, dengan menggunakan soal-soal non rutin kemampuan matematis siswa akan mampu dikembangkan lebih baik. Hal ini dikarenakan adanya aktivitas mental berupa penemuan pola, penggeneralisasi, komunikasi matematik dan lain-lain yang dapat dikembangkan secara lebih baik melalui pemecahan masalah. Selanjutnya, kurikulum yang dipakai di sekolah adalah kurikulum 2013. Pada dasarnya, kurikulum 2013 yang digunakan dalam pembelajaran matematika di sekolah memuat pentingnya kemampuan pemecahan masalah matematis yang dituangkan ke dalam kompetensi dasar. Sebagai contoh kompetensi dasar untuk materi pecahan yaitu menjelaskan dan menentukan urutan pada bilangan bulat (positif dan negatif) dan pecahan (biasa, campuran, desimal, persen). Adanya aktivitas menjelaskan, menentukan juga menerapkan merupakan aktivitas dari kemampuan pemecahan masalah yang masih belum maksimal untuk diterapkan dalam pembelajaran dan juga soal.

Oleh karena itu, pemberian soal tes kemampuan pemecahan masalah dalam bentuk soal non rutin/ open ended perlu untuk dilatihkan kepada siswa. Inovasi yang dapat diberikan agar soal open ended memberikan pengalaman langsung kepada siswa adalah dengan 
memanfaatkan budaya yang dijadikan konteks. Pemberian soal open ended berbasis kearifan lokal diharapkan menjadikan konteks pembelajaran menjadi "dekat" dengan siswa. Pentingnya pengintegrasian pembelajaran berbasis budaya ke dalam kurikulum matematika telah dilakukan oleh Sirate (S. Sirate, 2012) yang menyatakan bahwa etnomatematika dalam pembelajaran matematika sebagai sarana untuk memotivasi, menstimulasi siswa dalam mengatasi kejenuhan dan memberikan nuansa baru pada pembelajaran matematika. Muslimahayati (Muslimahayati, 2020) juga mengungkapkan bahwa implementasi penggunaan kearifan lokal pada pengembangan soal yaitu dapat menambah pengetahuan dan wawasan siswa terkait budaya dan kaitannya dengan pembelajaran. Memperkenalkan kearifan lokal dalam pembelajaran berguna untuk melestarikan kebudayaan lokal serta menjadikan pembelajaran menjadi lebih menarik dan lebih dekat kepada siswa ataupun mahasiswa.

Yusuf, Zulkardi dan Saleh (Yusuf, Zulkardi, \& Saleh, 2013), juga memberikan gambaran yang tampak dalam bidang pendidikan selama ini, pembelajaran menekankan lebih pada hafalan dan mencari satu jawaban yang benar untuk soal-soal yang diberikan, proses pemikiran tinggi termasuk berpikir kreatif jarang dilatihkan. Padahal, sesuai dengan tujuan dari pembelajaran matematika bahwa matematika bukan hanya sekedar hafalan, namun siswa harus mampu bernalar, menyampaikan ide, memecahkan masalah serta memberikan sikap positif terhadap matematika.

Konteks yang digunakan agar pembelajaran menjadi "dekat" dengan siswa dalam penelitian ini adalah konteks kearifan lokal budaya Jambi.
Hal ini dikarenakan kebudayaan Jambi masih belum tereksplorasi optimal dan belum dijadikan konteks untuk soal. Provinsi Jambi adalah salah satu provinsi di Indonesia yang dahulu menjadi salah satu pusat kebudayaan. Ada dua kerajaan besar yang pernah berkembang di wilayah ini yaitu kerajaan Melayu dan Jambi. Begitu banyak peninggalanpeninggalan seperti candi muaro jambi, situs karang berahi, makam raja-raja, rumah adat, bahasa, kesenian, permainan tradisional, batik khas Jambi, makanan tradisional dan juga ada suku-suku khas provinsi Jambi. Hal ini menjadi bukti bahwa provinsi Jambi memiliki kebudayaan dan kearifan lokal yang unik. Berdasarkan latar belakang dan literatur yang telah dipaparkan maka salah satu usaha untuk mendeskripsikan kemampuan pemecahan masalah siswa adalah dengan pemberian soal-soal open ended yang berinovasi dengan menggunakan konteks kebudayaan.

\section{METODE PENELITIAN}

Penelitian ini adalah penelitian deskriptif kualitatif. Penelitian ini bertujuan untuk mendeskripsikan kemampuan pemecahan masalah siswa dalam menyelesaikan soal open ended berbasis budaya Jambi pada materi pecahan. Penelitian dilaksanakan di MTs Negeri 3 Kota Jambi. Subjek penelitian adalah siswa kelas VII MTs Negeri 3 Kota Jambi yang terdiri dari 6 siswa. Adapun siswa terdiri dari 2 siswa berkemampuan tinggi, 2 siswa berkemampuan sedang dan 2 siswa berkemampuan rendah. Pemilihan sampel penelitian dilakukan dengan teknik purposive sampling dimana sampel dipilih berdasarkan tingkat kemampuan tinggi, sedang dan rendah serta pemahaman mengenai budaya daerah yang cukup baik. Instrumen yang digunakan adalah tes dan wawancara. 
Analisis data dilakukan dengan reduksi data, penyajian data dan verifikasi atau kesimpulan. Teknik keabsahan data dilakukan dengan triangulasi sumber data. Penelitian dilakukan pada masa pandemi Covid-19 sehingga penelitian dilakukan dalam jaringan (online) dengan memanfaatkan teknologi seperti aplikasi google meet, whatsapp group, dan google form. Penelitian terlaksana dengan dibantu oleh guru mata pelajaran untuk memantau keefektifan jalannya tes.

Terdapat lima indikator kemampuan pemecahan masalah yang akan dideskripsikan yaitu; (1) mengidentifikasi unsur-unsur yang diketahui, ditanyakan dan kecukupan unsur yang diperlukan (memahami masalah); (2) merumuskan masalah matematika atau menyusun model matematika; (3) menerapkan strategi untuk menyelesaikan berbagai masalah (sejenis dan masalah baru) dalam atau diluar matematika; (4) menjelaskan hasil sesuai permasalahan asal; (5) menggunakan matematika secara bermakna. Kelima indikator ini dituangkan ke dalam enam soal open ended berbasis kearifan lokal budaya Jambi pada materi pecahan. Adapun kearifan lokal budaya Jambi yang menjadi konteks dalam soal yaitu kue putri kandis, batik Jambi motif bungo kopi dan permainan tradisional buntang kaleng. Kriteria pedoman penskoran soal open ended dapat dilihat pada Tabel 1.

Tabel 1. Pedoman penskoran nilai tes soal-soal open-ended.

\begin{tabular}{cl}
\hline Skor & Jawaban yang Diberikan oleh Siswa \\
\hline 0 & Poin responden menunjukkan pemahaman tak cukup tentang konsep yang \\
& esensial. Jika ada prosedur mengandung banyak kesalahan, tidak ada \\
penyelesaian tentang solusi atau pembaca/penilai tak mampu memahami & \\
penjelasan siswa & $\begin{array}{l}\text { Poin responden menunjukkan pemahaman yang terbatas tentang konsep } \\
\text { matematika yang esensial. Respon dan prosedur tidak lengkap atau }\end{array}$ \\
mengandung kesalahan yang banyak. Penjelasan tidak lengkap bagaimana \\
masalah itu diselesaikan \\
$\begin{array}{l}\text { Penjelasan bagaimana masalah itu diselesaikan tidak begitu jelas } \\
\text { menyebabkan pembaca/penilai mendapatkan sedikit kebingungan. Respon }\end{array}$ \\
hampir memiliki pemahaman yang lengkap tentang konsep \\
Semuanya benar atau mempunyai sedikit saja kesalahan. Respon mencakup \\
penjelasan yang jelas dan efektif, mendetail bagaimana masalah itu \\
diselesaikan sehingga pembaca/penilai tidak lagi
\end{tabular}

Setelah memberikan penskoran terhadap hasil siswa dalam mengerjakan soal open ended, hal selanjutnya yang dilakukan adalah mengkategorikan skor yang diperoleh siswa ke dalam tingkat kemampuan pemecahan masalah siswa sesuai dengan kriteria yang disajikan pada Tabel 2.
Tabel 2. Kategori kemampuan pemecahan masalah siswa.

\begin{tabular}{cc}
\hline Nilai Siswa & Kategori \\
\hline $81-100$ & Sangat Baik \\
$61-80$ & Baik \\
$41-60$ & Cukup \\
$21-40$ & Kurang \\
$0-20$ & Sangat Kurang \\
\hline
\end{tabular}


DOI: https://doi.org/10.24127/ajpm.v10i1.3122

\section{HASIL DAN PEMBAHASAN}

Pelaksanaan penelitian dilakukan dengan memberikan soal kemampuan pemecahan masalah dalam bentuk open ended problem kepada 6 siswa kelas VII di MTs Negeri 3 Kota Jambi yang terdiri dari 2 siswa berkemampuan tinggi (A1 dan A2), 2 siswa berkemampuan sedang (A3 dan A4) dan 2 siswa berkemampuan rendah (A5 dan A6). Soal open ended tersebut dikembangkan berdasarkan indikator kemampuan pemecahan masalah. Hasil skor tes kemampuan pemecahan masalah dari 6 siswa dapat dilihat pada Tabel 3.

Tabel 3. Skor tes kemampuan pemecahan masalah.

\begin{tabular}{ccccccc}
\hline \multirow{2}{*}{ Siswa } & \multicolumn{7}{c}{ Indikator } & \multirow{2}{*}{ Total } \\
\cline { 2 - 6 } & $\mathbf{1}$ & $\mathbf{2}$ & $\mathbf{3}$ & $\mathbf{4}$ & $\mathbf{5}$ & \\
\hline A1 & 1 & 1 & 1 & 1 & 0 & 4 \\
A2 & 3 & 3 & 3 & 3 & 3 & 15 \\
A3 & 3 & 3 & 1 & 1 & 3 & 11 \\
A4 & 3 & 3 & 1 & 1 & 3 & 11 \\
A5 & 1 & 1 & 0 & 3 & 0 & 5 \\
A6 & 1 & 0 & 0 & 0 & 2 & 3 \\
\hline \multicolumn{5}{c}{ Rata-rata (dalam skala 100) } & 54,4 \\
\hline
\end{tabular}

Berdasarkan tabel 3 didapatkan rata-rata tes kemampuan pemecahan masalah matematis siswa adalah 54,4 dengan kategori cukup. Terlihat bahwa dalam proses menyelesaikan masalah berdasarkan tingkat kemampuan tinggi, sedang dan rendah mendapat hasil yang berbeda pula. Berikut deskripsi kemampuan pemecahan masalah berdasarkan tingkat kemampuan siswa.

\section{Kemampuan pemecahan masalah siswa berkemampuan tinggi dalam menyelesaikan soal open ended berbasis budaya Jambi}

Berdasarkan lembar jawaban tertulis, siswa yang berkemampuan tinggi (A1 dan A2) mendapatkan skor berturut-turut 4 dan 15 dengan rata-rata 63,33 (dalam skala 100). Skor tersebut tergolong pada kategori baik. Secara individu, siswa A2 menjawab semua soal dengan jawaban yang tepat dan benar. Sebagai contoh untuk soal nomor 4 dengan indikator siswa mampu menyusun model matematika yang sesuai dengan menggambarkan motif bungo kopi pada persegi yang tersedia, jawaban siswa dapat dilihat pada Gambar 1.

Diket dari gambar $7, \frac{3}{10}$ motif bungo kopi yang terisi, ditanya berapa motif bungo kopi yang harus diisi untuk menyatakan $\frac{4}{5} / \frac{8}{10}$ telah terisi motif bungo kopi

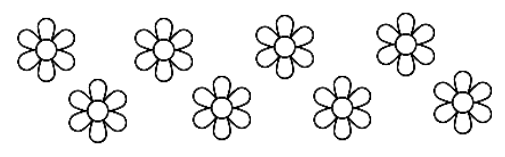

\section{Gambar 1. Jawaban siswa A2}

Pada Gambar 1 siswa A2 menggambarkan ilustrasi yang tepat untuk pertanyaan yang diajukan yaitu pecahan senilai dengan pecahan $\frac{4}{5}$, yaitu dengan menggambarkan 8 motif bunga kopi pada 10 kotak persegi yang tersedia. Berdasarkan jawaban ini dapat dilihat bahwa siswa A2 memahami dan mampu untuk memodelkan pecahan yang senilai dengan pecahan $\frac{4}{5}$ yaitu pecahan $\frac{8}{10}$. Begitupula dengan soal lainnya, siswa A2 menjawab dengan benar sehingga dapat dinilai bahwa siswa A2 telah memenuhi semua indikator kemampuan pemecahan masalah yang sangat baik.

Di lain pihak, siswa A1 terlihat kesulitan dalam menjawab persoalan. Berdasarkan lembar jawaban tertulis, skor total yang diperoleh adalah 4 atau 26,67 (dalam skala 100) dengan soal nomor 5 tidak dijawab sehingga 
mendapat nilai nol. Sehingga, siswa A1 masih tergolong kurang dalam kemampuan pemecahan masalah. Kesulitan yang dihadapi oleh siswa A1 berdasarkan hasil wawancara adalah siswa merasa soal yang diberikan kurang jelas, hal ini mungkin dikarenakan soal yang diberikan adalah soal terbuka yang informasi dalam soal memang sedikit sehingga siswa memerlukan beberapa metode penyelesaian atau beberapa alternatif jawaban. Keterbukaan ini yang membuat siswa A1 merasa sulit dalam memahami persoalan. Sementara itu, siswa belum terbiasa untuk mengerjakan soal terbuka. Kesulitan lain adalah siswa belum terbiasa mengerjakan secara mandiri soal-soal yang berbentuk open ended, sehingga perlu adanya latihan serta pendampingan untuk siswa dalam mengerjakan soal-soal yang menuntut daya pikir tingkat tinggi. Namun, walau dirasa sulit, siswa A1 dalam wawancaranya tetap merasa tertantang dalam mengerjakan soal, siswa juga merasakan bahwa soal yang mempunyai konteks kearifan lokal lebih menarik dibanding soal pada umumnya.

\section{Kemampuan pemecahan masalah siswa berkemampuan sedang dalam menyelesaikan soal open ended berbasis budaya Jambi}

Berdasarkan lembar jawaban diketahui bahwa siswa dengan kemampuan sedang (A3 dan A4) mendapatkan skor sama yaitu 11 dengan rata-rata 73,3 (dalam skala 100) yang tergolong pada kategori baik. Sebagai contoh soal nomor 5 : Jika seorang anak menggunakan cara berikut ini untuk menentukan nilai dari $\frac{1}{2}+\frac{2}{3}$ yang sama dengan $\frac{3}{5}$. Apakah hal tersebut benar? Jelaskan jawabanmu!, Salah satu contoh jawaban siswa terlihat pada Gambar 2.

$$
\begin{aligned}
& \text { 5. Salah } \\
& \frac{1}{2}+\frac{2}{3}=\frac{3}{6}+\frac{4}{6}=\frac{7}{6}
\end{aligned}
$$

\section{Gambar 2. Jawaban siswa A3}

Pada Gambar 2 terlihat bahwa siswa A3 mampu untuk berpikir logis dalam memahami prinsip penjumlahan pecahan secara bermakna. Siswa mengetahui kesalahan dalam penjumlahan bahkan mampu memberikan jawaban yang benar secara tepat. Tidak jauh berbeda dengan siswa A3, siswa A4 juga memiliki penyelesaian yang serupa dengan siswa A3. Berdasarkan lembar jawaban dapat dinilai bahwa siswa A3 dan A4 memiliki kemampuan pemecahan masalah yang baik. Selanjutnya, berdasarkan hasil wawancara terlihat bahwa siswa A3 dan A5 merasa tertantang dan tertarik dalam mengerjakan soal kemampuan pemecahan masalah dalam bentuk open ended problem berbasis kearifan lokal budaya Jambi.

Kemampuan pemecahan masalah siswa berkemampuan rendah dalam menyelesaikan soal open ended berbasis budaya Jambi

Berdasarkan lembar jawaban diketahui bahwa siswa dengan kemampuan rendah (A5 dan A6) mendapatkan skor 5 dan 3 dengan ratarata 26,67 (dalam skala 100) tergolong pada kategori kurang memenuhi indikator kemampuan pemecahan masalah dan perlu untuk latihan serta bimbingan. Siswa dengan kemampuan rendah mengalami kesulitan dalam memahami maksud persoalan serta kesulitan dalam mentransformasikan konteks soal ke dalam model matematika. Sebagai contoh pada soal nomor 1 yang ditanyakan; berapakah perkiraan nilai pecahan yang sesuai 
untuk menyatakan bagian yang terarsir? Berikan alasan jawabanmu, namun jawaban dari siswa melenceng kepada luas dari persegi. Hal ini dapat dilihat pada Gambar 3.

1. Rumus persegi $=$ panjang $x$ lebar

$$
=4 \mathrm{~cm} \times 4 \mathrm{~cm}
$$

Jawaban $1=1: 4$

$$
\begin{aligned}
& =4 \times 4: \frac{1}{4} \\
& =\frac{1}{4} \times 16 \\
& =4
\end{aligned}
$$

Jawaban $2=\frac{1}{2} \mathrm{x}$ alas $\mathrm{x}$ tinggi $\mathrm{x}$ total

$$
\begin{aligned}
& =\frac{1}{2} \times 2 \times 2 \times 8 \\
& =\frac{1}{2} \times 32 \\
& =16
\end{aligned}
$$

Gambar 3. Jawaban siswa A6

Pertanyaan yang diajukan adalah terkait perkiraan arsiran pecahan, siswa A6 menjawab dengan menggunakan konsep luas dari bangun datar. Hal ini tidak sesuai dengan apa yang ditanyakan soal. Temuan penelitian ini mengkonfirmasi temuan (Samo, 2017; Watson, J. M., \& Chick, 2001) yang mengungkapkan, salah satu faktor yang mempengaruhi kemampuan pemecahan masalah adalah faktor kemampuan kognitif dan pengalaman belajar. Oleh karena itu, dapat dinilai bahwa siswa A6 masih kurang memahami cara mentransformasikan konteks yang diberikan menjadi model matematika yang tepat. Tidak jauh berbeda siswa A5 hanya bisa menjawab soal nomor 4 dengan tepat. Namun untuk soal yang lain ada yang skor nya hanya 1 bahkan nol. Berdasarkan jawaban terlihat bahwa siswa A5 belum mampu menjelaskan permasalahan yang diberikan ke dalam bentuk matematika secara tepat. Walaupun siswa A5 dan A6 masih kurang mampu menjawab pertanyaan soal kemampuan pemecahan masalah, berdasarkan hasil wawancara para siswa merasa pembelajaran atau pemberian soal dengan menggunakan konteks budaya Jambi merupakan sesuatu yang cukup menantang dan menarik dalam pembelajaran.

Berdasarkan pemaparan hasil penelitian dan pembahasan, diketahui bahwa pembelajaran berbasis budaya menjadi sebuah metode baru bagi peserta didik untuk mentransformasikan hasil observasi mereka ke dalam bentuk dan prinsip yang kreatif tentang bidang ilmu. Sehingga penggunaan budaya dalam pembelajaran menjadi satu pilihan untuk "mendekatkan" pembelajaran matematika. Selain itu, penelitian ini sejalan dengan penerapan kurikulum 2013. Dalam penerapan kurikulum 2013, pembelajaran ditekankan pada saintis, inquiri, dan pemecahan masalah (Andriyani \& E, 2017). Sehingga kemampuan pemecahan masalah merupakan suatu hal yang perlu ditingkatkan terutama dalam pembelajaran matematika. Pembiasaan untuk mengerjakan soal non rutin baik berupa soal berpikir tingkat tinggi maupun juga soal open ended dapat meningkatkan kreatifitas dan daya pikir siswa dalam memecahkan masalah.

Penelitian ini menunjukkan bahwa siswa berkemampuan tinggi dan sedang berada pada kategori baik hal ini juga bersesuaian dengan penelitian (Samo, 2017) kemampuan mahasiswa pemecahan masalah geometri konteks budaya cenderung berbeda dalam tinjauan kemampuan individu. Mahasiswa berkemampuan tinggi cenderung lebih baik dalam memecahkan masalah dibandingkan dengan mahasiswa kemampuan sedang dan rendah. Masalah utama yang ditemukan adalah kurangnya 
pemahaman terhadap masalah serta formulasi masalah ke dalam model matematika. Temuan ini juga sejalan dengan (Hoiriyah, 2019) yang menyatakan bahwa pemberian soal-soal open-ended kepada mahasiswa dapat merangsang dan menumbung kembangkan kemampuan berpikir kreatif mahasiswa sehingga mampu melahirkan ataupun menciptakan ide-ide baru yang inovatif dan kreatif yang ada pada dirinya dalam memecahkan permasalahpermasalahan matematika. Penggunaan soal terbuka (open-ended problem) dalam pengembangan ini memberikan efek yang positif. Hal ini juga sesuai dengan penelitian (Nurlita, 2015) yang menyatakan bahwa prestasi belajar matematika siswa secara keseluruhan mencapai kategori positif.

Pengembangan soal open ended berbasis kearifan lokal budaya Jambi memberikan dampak positif terhadap siswa dalam pembelajaran matematika. Hal ini terlihat dengan antusiasme siswa pada wawancara yang mengatakan bahwa dengan mengerjakan soal ini siswa dapat memahami dan mendalami matematika serta dapat berpikir kreatif juga berpikir secara kritis. Melalui soal ini, siswa juga menjadi lebih kenal dengan budayanya, budaya Jambi yang sebelumnya sedikit terkikis oleh zaman. Ada permainan buntang kaleng, ada kue tradisional putri kandis, dan ada motif bungo kopi dari batik Jambi yang bisa diintegrasikan dengan pembelajaran matematika.

\section{KESIMPULAN DAN SARAN}

Berdasarkan hasil penelitian dan pembahasan dapat disimpulkan bahwa penelitian ini telah mendeskripsikan kemampuan pemecahan masalah matematis siswa pada kemampuan sedang dan tinggi tergolong pada kategori baik. Sedangkan untuk siswa kemampuan rendah berada pada kategori kurang sehingga siswa pada kemampuan rendah masih perlu bimbingan.

Soal open ended berbasis kearifan lokal sebagai sarana untuk mendeskripsikan kemampuan matematis sangat disarankan untuk digunakan. Selain itu, perlu untuk dikembangkan sesuai dengan latar belakang budaya kearifan lokal masing-masing juga dengan menggunakan materi yang berbeda pula. Hal ini dimaksudkan agar menciptakan suatu kondisi pengetahuan yang "dekat" dengan siswa, sehingga pembelajaran lebih bermakna.

\section{DAFTAR PUSTAKA}

Andriyani, \& E, K. (2017). Etnomatematika: Model Baru dalam Pembelajaran. Jurnal Gantang, II(2), 133-144.

Aziza, M. (2019). Kemampuan pemecahan masalah siswa dalam menyelesaikan soal tertutup dan terbuka pada pokok bahasan lingkaran. Pythagoras: Jurnal Pendidikan Matematika, 14(2), 126-138.

https://doi.org/10.21831/pg.v14i2.2 6563

Fitriana, N., \& Purwasih, L. A. (2018). Efektivitas LKS Berbasis Pendekatan Open-Ended terhadap Kemampuan Pemecahan Masalah Matematis Siswa SMP. AKSIOMA: Jurnal Program Studi Pendidikan Matematika, 7(3), 425-433.

Hoiriyah, D. (2019). Kemampuan Berpikir Kreatif Mahasiswa dalam. Jurnal Ilmu-Ilmu Pendidikan Dan Sains, 7(02), 201-212.

Muslimahayati, M. (2020). Pengembangan Soal Kemampuan Berpikir Kritis Berbasis Kearifan Lokal Sumatera Selatan Pada Materi Trigonometri. AKSIOMA: Jurnal Program Studi Pendidikan 
DOI: https://doi.org/10.24127/ajpm.v10i1.3122

Matematika, $\quad 9(1), \quad 12$. https://doi.org/10.24127/ajpm.v9i1. 2459

National Council of Teachers of Mathematics. (2000). Principles and Standard For School Mathematics. Virginia: NCTM.

Nurlita, M. (2015). Pengembangan Soal Terbuka (Open-Ended Problem) pada Mata Pelajaran Matematika SMP Kelas VIII. Pythagoras: Jurnal Pendidikan Matematika, 10(1), 38-49. https://doi.org/10.21831/pg.v10i1.9 106

Polya, G. (2014). How to solve it: A new aspect of mathematical method. New Jersey: Princeton University Press.

S. Sirate, F. (2012). Implementasi Etnomatematika Dalam Pembelajaran Matematika Pada Jenjang Pendidikan Sekolah Dasar. Lentera Pendidikan: Jurnal Ilmu Tarbiyah Dan Keguruan, 15(1), 41-54.

https://doi.org/10.24252/lp.2012v15 n1a4

Sapitri, Y., Utami, C., \& Mariyam, M. (2019). Analisis Kemampuan Pemecahan Masalah Matematis Siswa dalam Menyelesaikan Soal Open-Ended pada Materi Lingkaran Ditinjau dari Minat Belajar. Variabel, $2(1), \quad 16$. https://doi.org/10.26737/var.v2i1.10 28

Samo, D. D. (2017). Kemampuan pemecahan masalah matematika mahasiswa tahun pertama dalam memecahkan masalah geometri konteks budaya. Jurnal Riset Pendidikan Matematika, 4(2), 141. https://doi.org/10.21831/jrpm.v4i2. 13470
Suandito, B., Darmawijoyo, D., \& Purwoko, P. (2013). Pengembangan Soal Matematika Non Rutin Di Sma Xaverius 4 Palembang. Jurnal Pendidikan Matematika, 3(2), 1-13. https://doi.org/10.22342/jpm.3.2.32 5.

Thursina, A. F., \& Sutriyono. (2018). Profil Kemampuan Pemecahan Masalah Open Ended Pada Materi Bangun Datar Segiempat bagi Siswa SMP. 1(1), 96-102.

Watson, J. M., \& Chick, H. L. (2001). Factors influencing the outcomes of collaborative mathematical problem solving: An introduction. Mathematical Thinking and Learning, 3(2-3), 125-173.

Yanti, D., Widada, W., \& Zamzaili. (2018). Kemampuan Pemecahan Masalah Open Ended Peserta Didik Sekolah Negeri Dan Swasta Dalam Pembelajaran Matematika Realistik Berorientasi Etnomatematika Bengkulu. Jurnal Pendidikan Matematika Raflesia, 3(1), 203209.

https://doi.org/https://doi.org/10.31 186/jpmr.v3i1.6284

Yusuf, M., Zulkardi, Z., \& Saleh, T. (2013). Pengembangan Soal-Soal Open-Ended Pada Pokok Bahasan Segitiga Dan Segiempat Di Smp. Jurnal Pendidikan Matematika, $3(2)$. https://doi.org/10.22342/jpm.3.2.32 7. 